\title{
Optimizing Hotspot Areas for Ecological Planning and Management Based on Biodiversity and Ecosystem Services
}

\author{
XIAO Yang, OUYANG Zhiyun, XU Weihua, XIAO Yi, ZHENG Hua, XIAN Chaofan \\ (State Key Laboratory of Urban and Regional Ecology, Research Center for Eco-Environmental Sciences, Chinese Academy of Sci- \\ ences, Beijing 100085, China)
}

\begin{abstract}
The significance of biodiversity and ecosystem services are gradually recognized by human as an approach towards sustainability, so it is important to understand relationships and congruence between them to support conservation planning, especially in the hotspot areas with a prominent role in conservation. However, the management of most conservation hotspots mainly focused on biodiversity, and rarely concerned with ecosystem services. With the aim of proposing criteria for conservation strategies that contribute to the optimization of biodiversity and ecosystem services, in this study, a Geographic Information System (GIS)-based approach was designed to estimate and map the biodiversity and ecosystem services in Chongqing Municipality of China. Furthermore, the distributions of hotspot areas for biodiversity and ecosystem services were mapped based on the relationship between cumulative ecosystem services and areas. Finally the statistical analysis was processed focused on specific conservation objectives. The results showed that hotspot areas can conserve the most biodiversity but with the least ecosystem services under the conservation plans target to biodiversity conservation. In contrast, depending on the ecosystem services of interest, hotspot areas can conserve the largest ecosystem services but with the least biodiversity. By integrating biodiversity and ecosystem services into conservation plan, we found that the conservation and regeneration of these small areas, would contribute to a conservation of $44 \%$ of the biodiversity hotspot and $14 \%-42 \%$ of the ecosystem services hotspot. Moreover, the current nature reserve selection was not maximize the biodiversity and ecosystem services compared to integration strategy, indicating that hotspot areas conservation and selection is vital for optimization protection of biodiversity and ecosystem services, and has practical significance for natural resources and ecosystem management.
\end{abstract}

Keywords: biodiversity; ecosystem services; hotspot; nature reserve; Chongqing Municipality, China

Citation: Xiao Yang, Ouyang Zhiyun, Xu Weihua, Xiao Yi, Zheng Hua, Xian Chaofan, 2016. Optimizing hotspot areas for ecological planning and management based on biodiversity and ecosystem services. Chinese Geographical Science, 26(2): 256-269 doi: 10.1007/s11769-016-0803-4

\section{Introduction}

Biodiversity and ecosystem services intrinsically linked with each other and their interactions are critical to the human well-being. Biodiversity supports functions of ecosystem services, and the ecosystem services maintenance is regarded as the actions of biodiversity conservation because of the importance of such services in sustaining human livelihoods (Bookbinder et al., 1998; Egoh et al., 2009). Nevertheless, both biodiversity and ecosystem services are increasingly threatened by human activities (Balvanera et al., 2001; Millennium Ecosystem Assessment, 2005) with degrading them to be depauperate systems (Vitousek et al., 1997). Because ecosystems collectively support the biogeochemical processes that regulate the Earth system, the potential

Received date: 2015-05-25; accepted date: 2015-09-21

Foundation item: Under the auspices of National Key Technology Research and Development Program of China (No. 2011BAC09B08), Special Issue of National Remote Sensing Survey and Assessment of Eco-Environment Change Between 2000 and 2010 (No. STSN-04-01)

Corresponding author: OUYANG Zhiyun. E-mail: zyouyang@rcees.ac.cn

(C) Science Press, Northeast Institute of Geography and Agroecology, CAS and Springer-Verlag Berlin Heidelberg 2016 
ecological consequences of biodiversity degradation and services loss have aroused considerable interests worldwide (McCann, 2000). The conservation biologists and policy-makers all donate themselves to improve existing and future conservation strategies for the conservation of biodiversity and ecosystem services (Janzen, 1998; Balvanera et al., 2001; Daily and Matson, 2008; Goldman et al., 2008; Eigenbrod et al., 2009; De Groot et al., 2010). However, the interaction mechanisms between biodiversity and ecosystem services still remain unclear.

Currently, the management of most existing conservation areas mainly concerned with biodiversity conservation (Balvanera et al., 2001; Egoh et al., 2007) and largely ignored the maintenance of ecosystem services. Recently, some members of the conservation community have preferred the maintenance of ecosystem services as a strategy to conserve biodiversity, while others have criticized this strategy as a distraction from the aim of biodiversity conservation (Reyers et al., 2012). Recent research did not show the accordant options regarding the existence of strong relationships between the positive effects of biodiversity and ecosystem services. Whereas some studies proved that a poor relationship, a generally low correlation, or a moderate overlap exist between biodiversity and ecosystem services (Chan et al., 2006), and others had revealed a generally high overlap between biodiversity priorities and ecosystem services (Turner et al., 2007; Egoh et al., 2009).

Given this case, it is meaningful to understand the relationships between the conservation priorities for biodiversity and for ecosystem services (Bai et al., 2011). However, quantifying the levels and values of these services has been proven difficult (Nelson et al., 2009). Currently, researchers modeled quantitatively the supply of ecosystem services in a specific area with 'ecological production functions' -the degree of services provision depend on local critical variables (Chen et al., 2011; Zhang et al., 2012). Although these methods are superior to those with the land cover and habitat assessment benefits transfer approach (Costanza et al., 1997; Konarska et al., 2002; Zhao et al., 2004; Turner et al., 2007; Li et al., 2010), few studies focus on the complicated spatial heterogeneity influenced by climate, vegetation, soil texture, terrain and human activities, especially the hilly areas where natural resources and geographic features are highly heterogeneous. The vacancy in the study hindered the progresses of the local governments and stakeholders on protecting their resources and environment with limited funds and powers. Therefore, a reasonable and precise method for mapping ecosystem services is needed to explore the relationships between biodiversity and ecosystem services in hilly areas.

Recently, rapid population growth and urban development have accelerated the demands for food, housing and factories (Hunter et al., 2003), which resulted in the complex changes of ecosystem types. In addition, climate change (Miao et al., 2014) highlighted the role of ecosystems related to the functions of mitigation and adaption. However, there are few studies on the quantitative estimation of the biodiversity and ecosystem services, as well as the priority areas for planning and management.

The aim of this study was to map the biodiversity (habitat quality) and ecosystem services (soil conservation, carbon sequestration, water flow regulation, water yield and water purification) with a new combined method including the Universe Soil Loss Equation (USLE), the Carnegie Ames Stanford Approach (CASA), Integrated Valuation of Environmental Services and Tradeoffs (In VEST) and mathematical simulations. A detailed analysis of the spatial distribution and congruence among biodiversity and ecosystem services was present here, which may support the planners and policy makers to launch the strategies for ecosystem management. Moreover, we also examined the tradeoffs between the biodiversity and ecosystem services to discuss the possibility of developing an integrated conservation plan. To a certain extent, this work can contribute to the further realization of the quantitative estimates approach of biodiversity and ecosystem services, and the empirical ways to identify conservation hotspot in terms of protection of biodiversity and ecosystem services.

\section{Materials and Methods}

\subsection{Study area}

The study area $\left(28^{\circ} 10^{\prime}-32^{\circ} 13^{\prime} \mathrm{N}, 105^{\circ} 11^{\prime}-110^{\circ} 11^{\prime} \mathrm{E}\right)$ is located on the upper reaches of the Changjiang (Yangtze) River (Fig. 1), covering a total area of $82400 \mathrm{~km}^{2}$ with total population of $2.01 \times 10^{7}$. The geographic conditions of this area are complicated with lower lands 
in the west and higher lands in the east. The main constitution of surface type is formed by mountainous $(75.8 \%)$, plain $(6 \%)$ and hilly $(18.2 \%)$, with a variety of land cover types. The dominant soil types in this region are purple soil, yellow soil and paddy soil. The Chongqing owns a subtropical monsoon climate and, for most of the year, it experiences humid conditions with an annual mean temperature of $17^{\circ} \mathrm{C}-19^{\circ} \mathrm{C}$. The mean annual precipitation is approximately $1100 \mathrm{~mm}$. Rainfall is variable over time and $85 \%$ of the annual rainfalls occurs mainly during summer (6-9 months). The region's location in the Sichuan Basin causes it to have one of the lowest annual sunshine totals nationally, at only 1055 hours, lower than much of other places. Chongqing Municipality, one of the most important ecological security zones in China, is located on the upper reaches of the three gorges reservoir area (TGRA), which own the greatest water conservation project in the world. Recently, rapid population growth and urban expansion in this region have accelerated the demand for food, housing and factories, which have led a series of ecological environment problems (nature habitat loss, soil erosion, intensive greenhouse gas emission, flood disaster and serious water pollution).

\subsection{Data sources}

The information on distribution of land cover for three periods (2000, 2005 and 2010) was produced by the
Institute of Remote Sensing and Digital Earth, Chinese Academy of Sciences, using Landsat MSS and TM satellite remote sensing with an overall accuracy of approximately $86.4 \%$. Land cover types were divided into seven categories in this study, including forest, shrub, grassland, water, arable land, construct land and barren land. The meteorological data (including precipitation, temperature and total solar radiation at a monthly scale) from 2000 to 2010 was provided by the Chinese National Metrological Information Center/China Meteorological Administration (NMIC/CMA). Average annual potential evapotranspiration $\left(\mathrm{ET}_{\mathrm{o}}\right)$ was obtained by the modified Hargreaves equation, which can generate good results when information is uncertain (Droogers and Allen, 2002). This process was completed in interactive data language (IDL) which is a programming language used for data analysis. The soil map and associated soil attributes (including particle composition, nutrient content, soil depth and soil bulk density) were acquired from the Institute of Soil Science, Chinese Academy of Sciences, with a resolution of $1: 1000000$. The Moderate Resolution Imaging Spectroradiometer (MODIS) NDVI dataset from 2000 to 2010 was applied in the study with resolution of $250 \mathrm{~m}$, and the time interval was 16 days. Given the fact that these products may be affected by cloud, atmosphere, we used the asymmetric Gaussian function (AG) filter to reconstruct the NDVI time series dataset to reduce noise and improve data

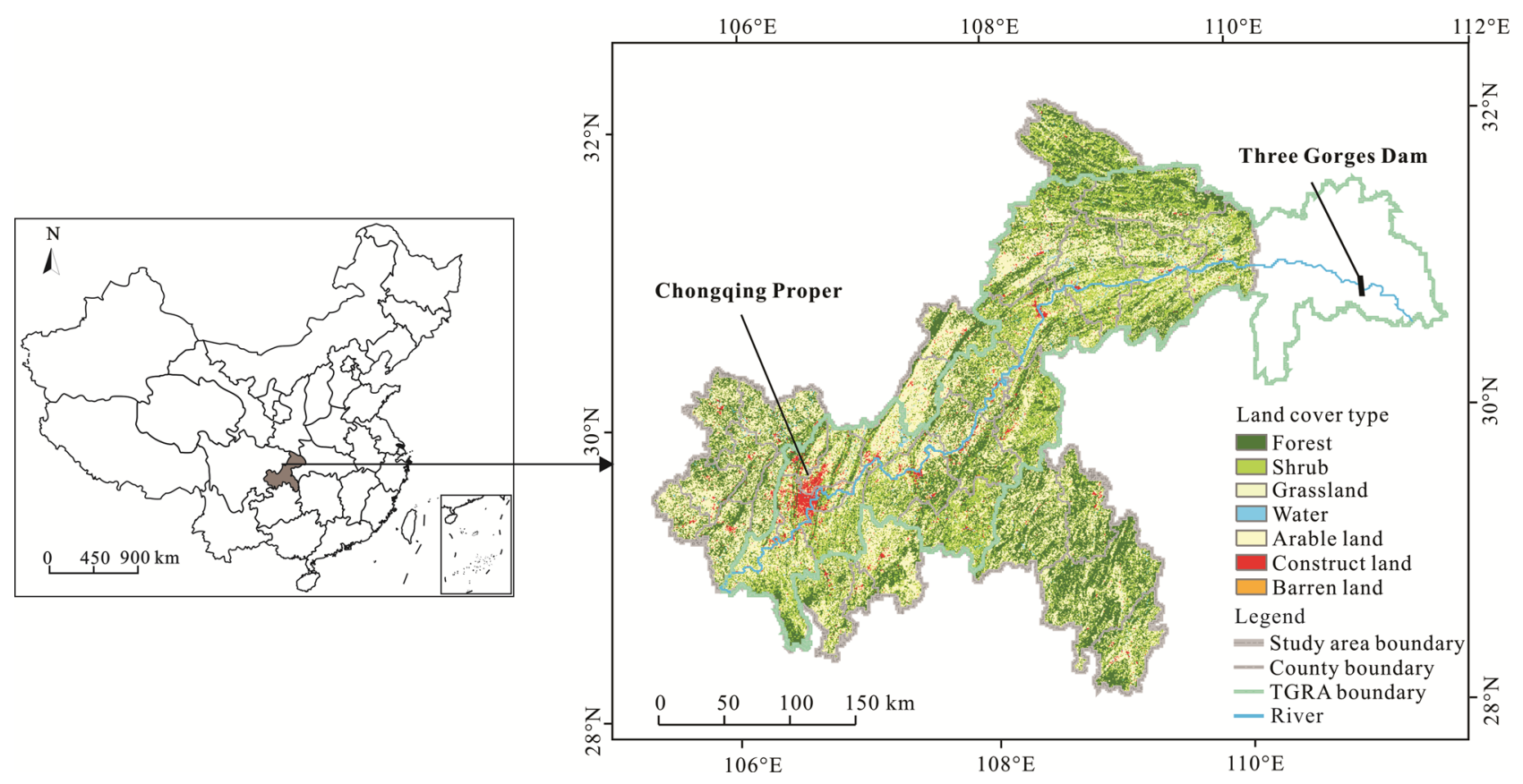

Fig. 1 Location and land cover distribution of Chongqing Municipality in China. TGRA, three gores reservoir area 
quality in the data pre-processing procedure based on the TIMESAT program (Jonsson and Eklundh, 2002; 2004). Plant available water content (PAWC) is defined as the difference between the fraction of volumetric field capacity and the permanent wilting point. We used Zhou's method (Zhou et al., 2005) to estimate PAWC. Topography data originated from Shuttle Radar Topography Mission (SRTM) digital elevation model data was provided by the International scientific data service platform. The watersheds and subwatersheds were gen- erated by using ArcSWAT based on a SRTM digital elevation model data. Maximum root depth was collected from Canadell et al. (1996), and the evapotranspiration coefficient table $(\mathrm{Kc})$ was estimated based on Allen et al. (1998) and the InVEST user guide. Moreover, observed and statistical data for model validation were collected from local government, hydrometricstation and several published works (Luo, 1996; Ni, 2004; Jin et al., 2007). The sources of the principal data are explained in Table 1.

Table 1 Sources of principal data

\begin{tabular}{lll}
\hline \multicolumn{1}{c}{ Data name } & \multicolumn{1}{c}{ Data scale } \\
\hline Land cover map & $90 \mathrm{~m}$ & Chinese Academy of Sciences \\
$\begin{array}{l}\text { Precipitation, temperature and } \\
\text { total solar radiation }\end{array}$ & 38 climatological stations and 6 & Chinese National Metrological Information Center/China \\
Soil map & solar radiation observation stations & Meteorological Administration (NMIC/CMA) \\
MODIS-NDVI & $1: 1000000$ & Chinese Academy of Sciences \\
SRTM digital elevation model & $250 \mathrm{~m}$ & Land Processes Distributed Active Archive Center (LP DAAC) \\
Natural reserve & $90 \mathrm{~m}$ & International scientific data service platform \\
Validation data & County & Chongqing Government \\
\hline
\end{tabular}

\subsection{Methods}

We analyze the degree of biodiversity (habitat quality) and the indexes of five important services in the study area: soil conservation, carbon sequestration, water flow regulation, water yield and water purification. These ecosystem services were selected on the basis of their significant role in this area, and their relevance to conservation planning and the availability of data.

\subsubsection{Biodiversity: habitat quality}

Biodiversity is intimately linked to the supply of ecosystem services. Patterns in biodiversity are inherently spatial, and can be estimated by analyzing maps of land cover in conjunction with threats. In this study, we modeled habitat quality as a proxy for biodiversity based on InVEST model, ultimately estimating the degree of habitat and vegetation types across a landscape (Tallis et al., 2010). The function of habitat quality is composed of four factors: the relative impact of each threat, the relative sensitivity of each habitat type to each threat, the distance between habitats and sources of threats, and the extent to which the land is legally protected (Tallis et al., 2010). Six threat factors (rural residential, urban, cropland, primary roads, secondary roads and light roads), which represent anthropogenic drivers in human-dominated landscapes, were considered. The quality of habitat $\left(Q_{x j}\right)$ in parcel $x$ that is in $\mathrm{LULC}_{j}$ can be calculated as:

$$
Q_{x j}=H_{j} \times\left(1-\left(\frac{D_{x j}^{z}}{D_{x j}^{z}+k^{z}}\right)\right)
$$

where $H_{j}$ is boolean map based on the user defining which LULC types can provide habitat for the conservation objective; $D_{x j}$ is the total threat level in grid cell $x$ with LULC $j$; and $z$ (we hard code $z=2.5$ ) and $k$ are scaling parameters (the half-saturation constant and is set by the user). The detailed calculation formula of $D_{x j}$ was described in the InVEST user's guide (Tallis et al., 2010).

\subsubsection{Soil conservation}

Soil erosion removes nutrients and reduces fertility (DeFries et al., 2004), and leads to the decreased hydropower output and the structural damage of reservoirs. The degree of soil conservation can be described as the difference between soil erosion without vegetation cover and soil erosion under the current land cover pattern and soil erosion control practice (Fu et al., 2011). The function of soil conservation based on USLE (Wischmeier and Smith, 1978; Lufafa et al., 2003) can be expressed as:

$$
S C=S E p-S E a=R \times K \times L S \times(1-C \times P)
$$

where $S C$ stands for the amount of soil conservation 
(t/(ha.yr)) ; SEp and $S E a$ denote the potential and actual soil erosion rates; $R$ is rainfall erosivity factor $(\mathrm{MJ} \cdot \mathrm{mm} /$ (ha.h.yr)), and was computed using monthly average rainfall with an empirical equation (Wisch-meier and Smith, 1978; Fu et al., 2011); $K$ is the soil erodibility factor (tha $\cdot \mathrm{h} /(\mathrm{ha} \cdot \mathrm{MJ} \cdot \mathrm{mm}))$ and was calculated using the modified equation based on the Erosion/Productivity Impact Calculator (EPIC) model (Zhang et al., 2008) so as to be consistent with the practical situation of China (Li et al., 2011); LS is the dimensionless topographic factor, and was calculated based on the methods developed by Hickey and Van Remortel (Hickey, 2000; Van Remortel et al., 2001) with the help of an Arc Macro Language (AML) script in ArcGIS; $C$ is dimensionless vegetation cover factor, and was estimated by the method using the form of NDVI (Li et al., 2011); $P$ is the dimensionless conservation practice factor. As to $P$ factor, the slope-based Wener method (Lufafa et al., 2003) was applied to calculate.

\subsubsection{Carbon sequestration}

Carbon sequestration is the process of capture and long-term storage of atmospheric carbon dioxide $\left(\mathrm{CO}_{2}\right)$ (Sedjo and Sohngen, 2012), which is proposed to be the mitigation to global warming. To quantify the amount of $\mathrm{CO}_{2}$ sequestrated annually by the ecosystem, we estimated net ecosystem productivity (NEP) as a proxy of carbon sequestration, and it can be defined as:

$$
N E P=N P P-R_{h}=N P P-0.592 \times R s^{0.714}
$$

where $N E P$ denotes the amount of carbon sequestration ( $\left.\mathrm{g} \mathrm{C} /\left(\mathrm{m}^{2} \cdot \mathrm{yr}\right)\right)$; net primary productivity $(N P P)$ is net fixation of $\mathrm{CO}_{2}$ by vegetation $\left(\mathrm{g} \mathrm{C} /\left(\mathrm{m}^{2} \cdot \mathrm{yr}\right)\right) ; R_{h}$ is soil heterotrophicrespiration from terrestrial ecosystems $\left(\mathrm{g} \mathrm{C} /\left(\mathrm{m}^{2} \cdot \mathrm{yr}\right)\right)$; $R s$ is soil respiration from terrestrial ecosystems $\left(\mathrm{g} \mathrm{C} /\left(\mathrm{m}^{2} \cdot \mathrm{yr}\right)\right)$.

As documented in Potter et al. (1993; 1999; 2003), the monthly NPP flux could be computed in CASA on the basis of light-use efficiency (LUE, Monteith, 1972). NPP can be calculated as:

$$
N P P=A P A R \times \varepsilon=S_{r} \times F P A R \times 0.5 \times \varepsilon_{\max } \times T s \times W s
$$

where monthly $N P P\left(\mathrm{~g} \mathrm{C}^{2} \mathrm{~m}^{2}\right)$ is the net primary productivity fixed by vegetation at a grid cell. APAR is the amount of photosynthetic active radiation, and is calculated by using the data on solar surface irradiance $S_{r}$ $\left(\mathrm{MJ} / \mathrm{m}^{2}\right)$ and the fractions of photosynthetic active radiation absorbed by green vegetation (FPAR). In addition, the constant 0.5 accounts for the fact that approxi- mately half of the incoming solar radiation is in the photosynthetic active radiation waveband (Potter et al., 1993). The factor $\varepsilon$ for each grid cell can be determined as the product of $\varepsilon_{\max }$ (monthly maximum utilization rate of light energy, g C/MJ) obtained by a calibration with field data, and stress scalars representing the availability of soil moisture $W_{s}$ and the suitability of temperature Ts (Potter et al., 1993; Crabtree et al., 2009).

The function of $R s$ according to Chen's research (Chen et al., 2012) can be expressed as:

$$
\begin{aligned}
& R s=1.55 \mathrm{e}^{0.031 \times T} \times P /(P+0.68) \times \\
& \left(0.58 \times B D \times H \times(1-\delta / 100) \times 10^{-1}\right) / \\
& \left(0.58 \times B D \times H \times(1-\delta / 100) \times 10^{-1}+2.23\right)
\end{aligned}
$$

where $R s$ is soil respiration rate $\left(\mathrm{kg} \mathrm{C} /\left(\mathrm{m}^{2} \cdot \mathrm{yr}\right) ; T\right.$ is average annual temperature $\left({ }^{\circ} \mathrm{C} / \mathrm{yr}\right) ; P$ is annual precipitation $(\mathrm{m} / \mathrm{yr}) ; B D$ is soil bulk density $\left(\mathrm{g} / \mathrm{cm}^{3}\right) ; H$ is soil depth $(20 \mathrm{~cm}) ; \delta$ is soil particles content that particle size is less than $2 \mathrm{~mm}$.

\subsubsection{Water yield}

The provision of fresh water is one of the important ecosystem services that contributes to the welfare of society, guarantying the development of irrigation agriculture, the improvement of living standards, the running of industry and tourism activities. In this study, we estimate the annual average quantity and identify the annual water yield contribution from each part of the landscape based on InVEST model (Tallis et al., 2010). The model does not incorporate sub-surface or ground water flows but it assumes that all precipitation without evapotranspiration flow into the surface run-off. The function of water yield (annual water flow) is based on the Budyko curve (Budyko, 1974) and annual average precipitation, it can be calculated as:

$$
R_{w}=\left(1-\frac{1+z \times \frac{A W C_{x}}{F_{x}} \times \frac{k_{x j} E T_{o x}}{P_{x}}}{1+z \times \frac{A W C_{x}}{P_{x}} \times \frac{k_{x j} E T_{o x}}{P_{x}}+\frac{F_{x}}{k_{x j} E T_{o x}}}\right) \times P_{x}
$$

where, $R_{w}$ is annual water yield for each pixel (mm/yr); $P_{x}$ is the annual precipitation on pixel (mm/yr); $A W C_{x}$ is the plant available water content $(\mathrm{mm} / \mathrm{yr}) ; z$ is a seasonality factor that presents the seasonal rainfall distribution and rainfall depths (Zhang et al., 2001); $k_{x j}$ is the vegetation evapotranspiration coefficient associated with the LULC $j$ on pixel $x$ and $E T_{o x}$ is the reference 
evapotranspiration from pixel $x$ computed with reference to Hargreaves equation (Hargreaves and Samani, 1985). After repeated validation, the water yield was relatively similar to natural runoff when the $Z$ value was 3.0.

\subsubsection{Water flow regulation}

Land covers such as forests, forested wetlands and shrub etc. have impacts on the timing and magnitude of water runoff and water flows (Hewlett, 1982). They act as sponges, intercepting rainfall and absorbing water through root systems. The water flow regulation services that forests provide can yield economic benefits to communities. During stormy weather, forests can capture redundant water runoff instead of municipal reservoir. Water flow regulation service is measured by the fraction of the annual water flow stored in the soil (Onaindia et al., 2013). The function of the water flow regulation can be expressed as:

$W F R=H u / R_{w}$

where $W F R$ is the water flow regulation, $H u$ is the water storage in the soil $(\mathrm{mm} / \mathrm{yr})$. The water storage in the soil map is estimated by the effective thickness of soil, soil bulk density and the maximum effective water capacity. $R w$ is the annual water flow ( $\mathrm{mm} / \mathrm{yr}$ ) and was calculated based on InVEST model (Tallis et al., 2010).

\subsubsection{Water purification: phosphorus retention}

Rapid population growth, urbanization and industry development had brought great pressure to ecosystem (Hunter et al., 2003). River is polluted by urban domestic sewage, industrial waste, pesticides and fertilizers. The removal of surplus nutrients and filtration of drinking water are regarded as the important services provided by ecosystems. Our study focus on phosphorus (P) pollution as a proxy for non-point-source pollution. The InVEST model (Tallis et al., 2010) was applied to estimate the amount of nutrient retained on every pixel. Then we summed and averaged the amount of nutrient export and retention per sub-watershed, respectively. The quantity of pollutants retained for water purification from a landscape was calculated based on export coefficients, being defined as follows:

$$
A L V_{x}=\log \left(\sum_{U} Y_{u} / \overline{\lambda W} \times p o l_{x}\right)
$$

where $A L V_{x}$ is the Adjusted Loading Value at pixel $x$ $(\mathrm{kg} /(\mathrm{ha} \cdot \mathrm{yr})) ; Y_{u}$ is the water yield of pixels along the flow path above pixel $x ; \lambda W$ is the runoff index in the watershed of interest; $\operatorname{pol}_{x}$ is the export coefficient at pixel $x$.

\subsubsection{Identifying hotspot}

The term 'hotspot' was originally used for regions with high species richness and has been widely applied to prioritize areas for biodiversity conservation (Van Jaarsveld et al., 1998). In this study, we define hotspot as 'a significant area that have a prominent role in conservation biology and provide large amounts of ecosystem services' (Orme et al., 2005; Egoh et al., 2008; Egoh et al., 2009). Meanwhile, the range defined as 'areas with meaningful supply' is similar to a species' range or area of occupancy (Egoh et al., 2008). Hotspot was delineated as the richest $10 \%$ of grid cells for each service, compared to the traditional proportionality coefficient 'five percent or less' (Prendergast et al., 1993; van Jaarsveld et al., 1998; Orme et al., 2005; Chan et al., 2006). The term range is used to refer to the areas which provide medium proportions of ecosystem services. Generally, the information of this threshold is lacking. Here, we adopted the arbitrary threshold (the remaining richest $40 \%$ of grid cells) to delineated the range areas. The integrated ecosystem services were formed by overlaying each important service after reclassification at the interval $10 \%$. In order to identify the optimal plan for ecological planning and management, three conservation strategies were comparatively analyze. Strategy 1 identified hotspot areas with the objective of conservation focusing on the intrinsic value of biodiversity. Strategy 2 preferred the hotspot areas for conservation with the objective focused on ecosystem services for human well-being. In strategy 3 , the hotspot areas with conservation objective to protect both biodiversity and ecosystem services were targeted based on integrated ecosystem services.

\subsubsection{Statistical analysis}

To explore the relationship between simulated results and observation-based data, the Pearson correlation was performed. The Pearson correlation was conducted with statistical units of county, quadrat and watershed, respectively, and statistical analyses was implemented using SPSS 17.0.

\section{Results}

\subsection{Models validation}

The distributions of habitat quality (county), soil erosion 
(county), NPP (quadrat), water yield (watershed) and phosphorus export (watershed) were modeled by the application of USLE, CASA and InVEST. To verify the regional applicability and reliability of these models, we validated the exported results based on observed data, which were collected from soil conservation monitoring stations and hydrometric stations in the study area from 2000 to 2010 , with the field-based forest biomass/NPP data from Luo's (1996) study, and data about the richness of wild vertebrate species and vascular plant species from local government. Significant correlations were revealed between simulated results and observation-based data (habitat quality: $r=0.715, P<0.01, n=$ 35; soil erosion: $r=0.816, P<0.01, n=35$; NPP: $r=$ $0.717, P<0.01, n=54$; water yield: $r=0.861, P<0.01$, $n=11$; phosphorus export: $r=0.866, P<0.01, n=12$ ). These indicated that the simulated models (USLE, CASA and InVEST) can be applied for the modeling of the habitat quality, soil erosion, NPP, water yield and phosphorus export across the study area. Some details concerning the correlations validation are explained in Fig. 2.

\subsection{Biodiversity and ecosystem services}

Spatial distributions of biodiversity and ecosystem ser- vices were obviously different (Fig. 3). The ecosystem in the northeastern and southeastern mountains with wide distribution of forest generally provided more valuable services such as soil conservation (values $>$ $400 \mathrm{t} / \mathrm{ha}$ ), carbon sequestration (values $>100 \mathrm{~g} \mathrm{C} / \mathrm{m}^{2}$ ), water flow regulation (values $>30 \%$ ) and water yield (values $>750 \mathrm{~mm} / \mathrm{ha}$ ) than those provided by western agricultural plain and developed urban areas. On the contrary, the service of phosphorus retention (values $>$ $15 \mathrm{~kg} / \mathrm{ha}$ ) mainly was originated from lower-elevation western part, where the agricultural land was the dominant ecosystem. Greater habitat quality (values $>70$ ) was mainly found in the high mountain areas within northeastern mountains with less anthropogenic disturbances, while the inferior habitat quality (values $<50$ ) was distributed in the western residential areas along the Changjiang River.

\subsection{Identifying hotspot areas}

The Fig. 4 showed that more land loss resulted in the greater devaluation of biodiversity and ecosystem services. The service of phosphorus retention showed a distinct declining trend (slope absolute value greater than 1) before the percentage of loss area reaching $20 \%$. It indicated that the amount of phosphorus retention
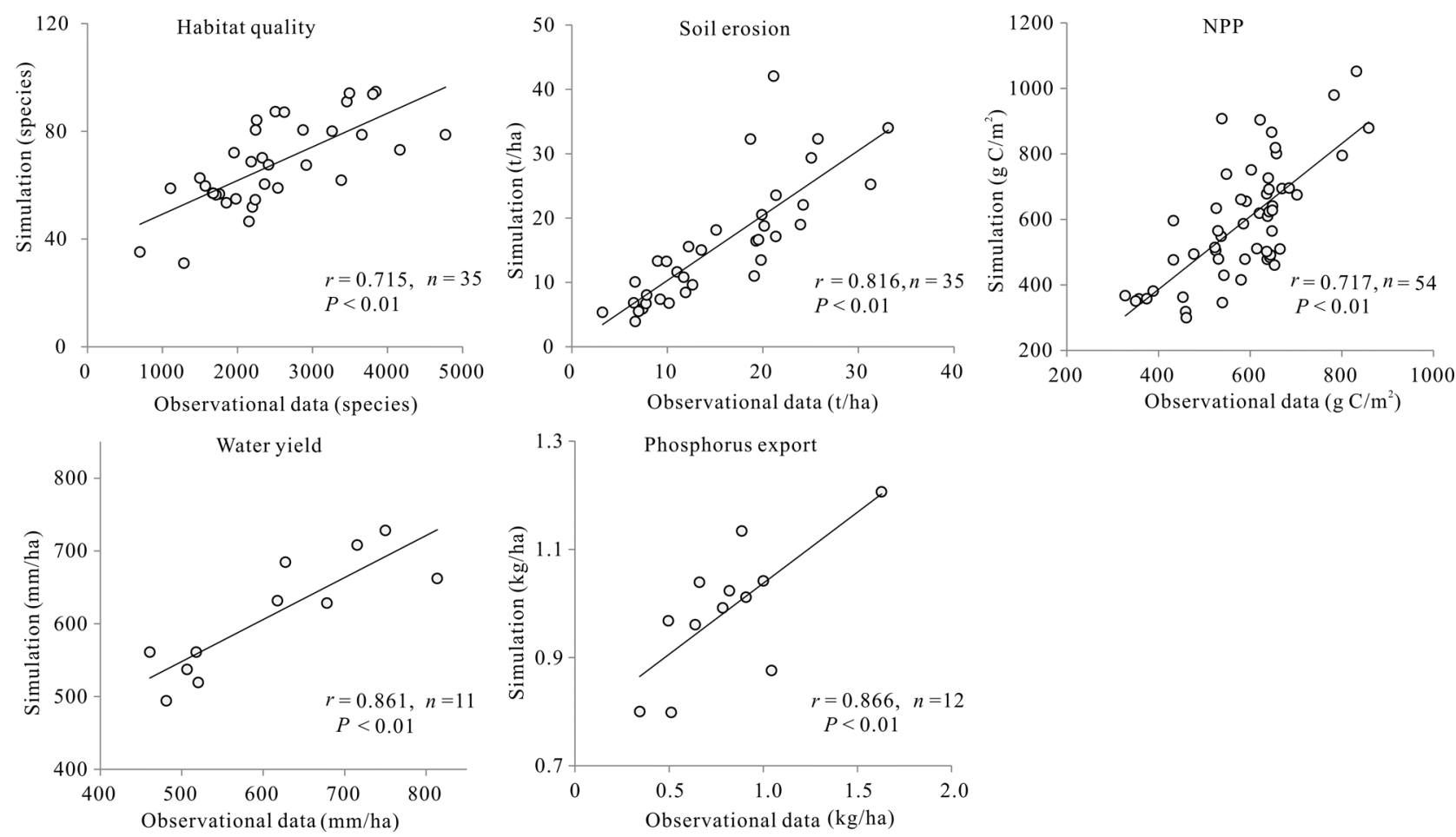

Fig. 2 Correlation validation of USLE model, CASA model and InVEST model. Simulations (habitat quality, soil erosion, NPP, water yield and phosphorus export) and observations value 

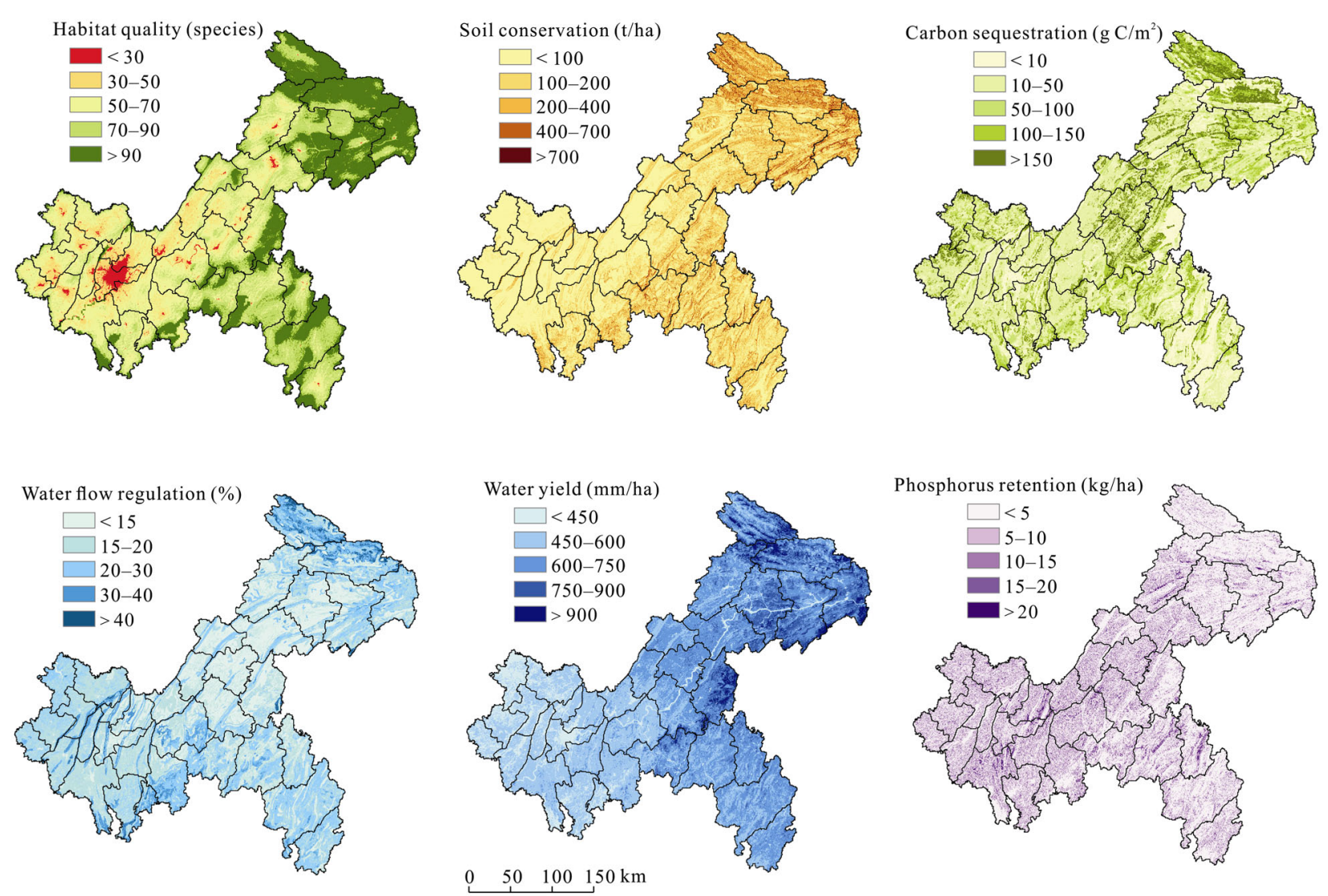

Fig. 3 Map of spatial distributions of habitat quality, soil conservation, carbon sequestration, water flow regulation, water yield and phosphorus retention

mainly occur on this $20 \%$ area, followed by carbon sequestration and soil retention, which declined before the percentages of loss area reaching $25 \%$ and $30 \%$. However, habitat quality, water flow regulation and water yield had no significant downward trend (slope absolute value close to 1). Moreover, the hotspot area (about $10 \%$ of total area) for phosphorus retention, carbon sequestration and soil retention provided greater ecosystem services with contribution of $74.3 \%, 44.6 \%$ and $37.7 \%$ to the ecosystem services, respectively. The other hotspot area of habitat quality, water flow regulation and water yield did not contribute significantly to the ecosystem services.

The maps of the hotspot and range area clearly revealed the distribution of the importance for biodiversity and ecosystem services (Fig. 5). The degree of habitat quality, soil conservation, carbon sequestration and water yield were higher in the east, while the areas with higher degree of water flow regulation and phosphorus retention were mostly located across the central and western parts.

\subsection{Optimizing hotspot areas}

In this study, we comparatively analyzed three different protection strategies to identify the optimal plan for environmental planning and management. The identification of hotspot for strategy 1 was based on the conservation target focusing on the intrinsic value of habitat quality. In this strategy, we kept the hotspot area for habitat quality unchanged, and used it as a mask to analyze the area percentages of hotspot and range for each ecosystem service. The greatest habitat quality existed within the mask with a $100 \%$ hotspot area, however, the degrees of ecosystem services were lowest, with the hotspot area about 4\%-29\% and range area about $47 \%-54 \%$ (Fig. 6a). Strategy 2 preferred the hotspot areas for conservation of ecosystem services for human well-being. In this strategy, we unchanged the hotspot area of integrated ecosystem services, and analyzed the area percentages of hotspot and range of habitat quality, as well as each ecosystem service within the unchanged hotspot area. The degrees of ecosystem services were largest, with the hotspot area 
about $20 \%-43 \%$ and range area about $47 \%-58 \%$, while the degree of habitat quality was very low (Fig. 6b). In strategy 3 , the hotspot areas focusing on the protection of both biodiversity and ecosystem services were used as a analysis mask. There were a greater degree of habitat quality with hotspot area about $44 \%$ and range area about $53 \%$, and ecosystem services with hotspot area about $14 \%-42 \%$ and range area about $49 \%-63 \%$
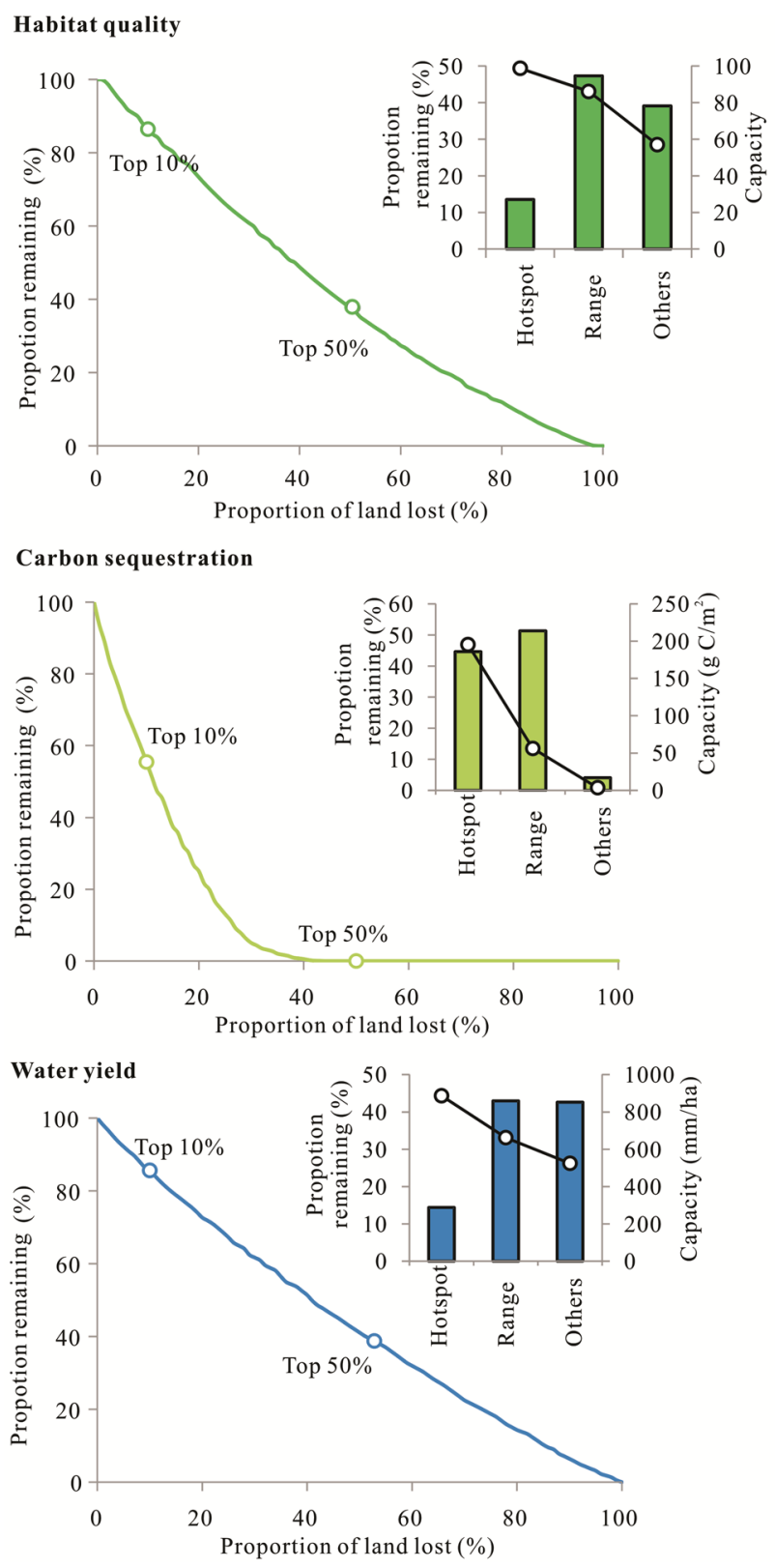

(Fig. 6c). Moreover, we further analyzed the proportions of key area for biodiversity and ecosystem services under the current nature reserves. The higher habitat quality was presented with the hotspot area about $68 \%$ and range area about $28 \%$, and the less ecosystem services were found, with the hotspot area about 4\%-24\% and range area about $42 \%-56 \%$ (Fig. $6 d)$.

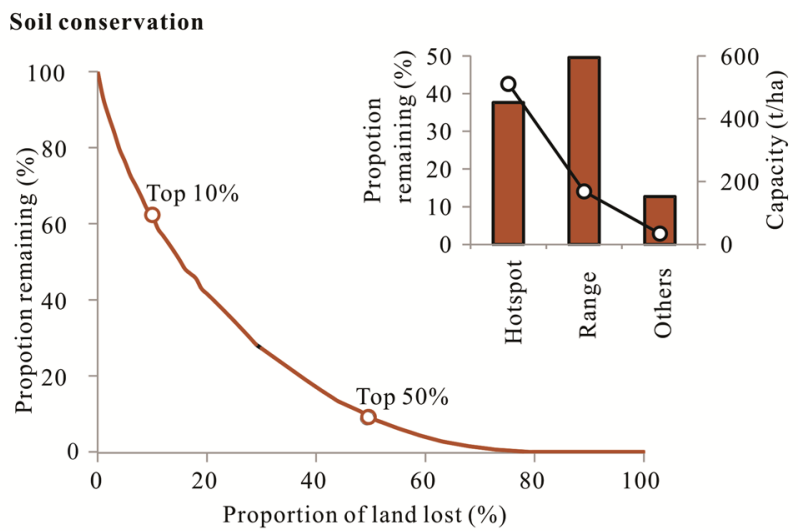

Water flow regulation
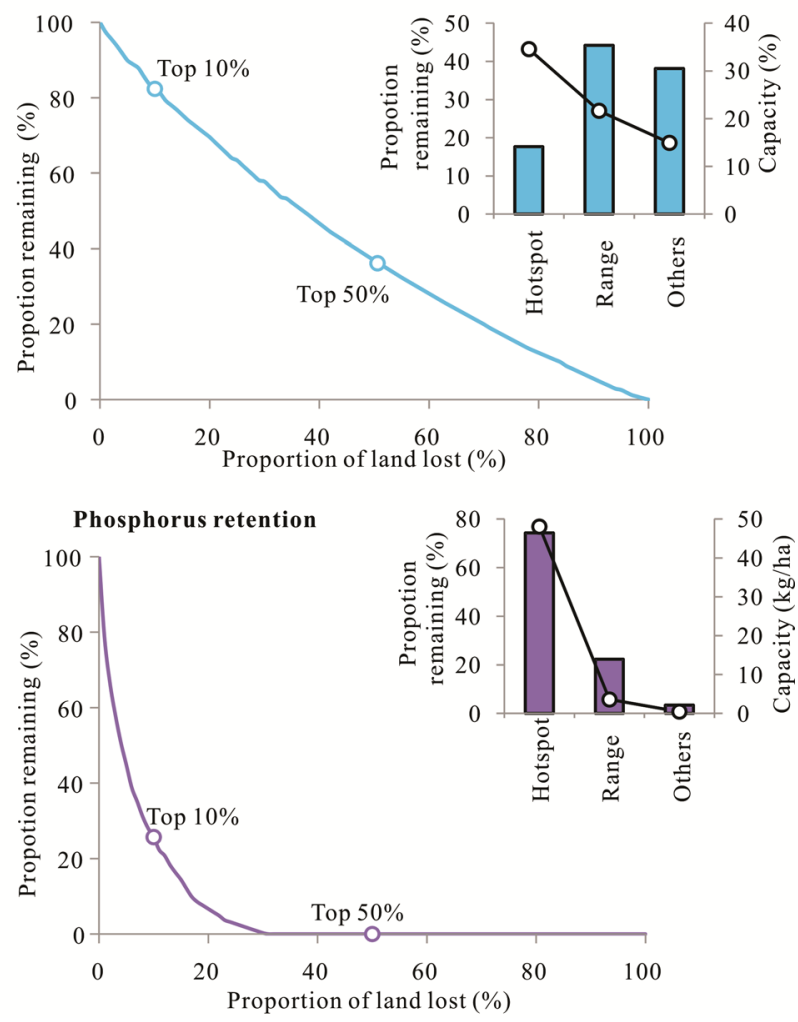

Fig. 4 Relationship between loss area and amount of significant value for habitat quality, soil conservation, carbon sequestration, water flow regulation, water yield and phosphorus retention (Note: the $x$-axis represents the fraction of lands lost from conservation, and the $y$-axis represents what remains for that feature; in the full land everything remains. Top 10\% and Top 50\% are the threshold points that identify the hotspot, range and other. The picture located in the upper right corner of each figure represents fraction of ecosystem services (bar graph) and capacity (point-line curve)) 

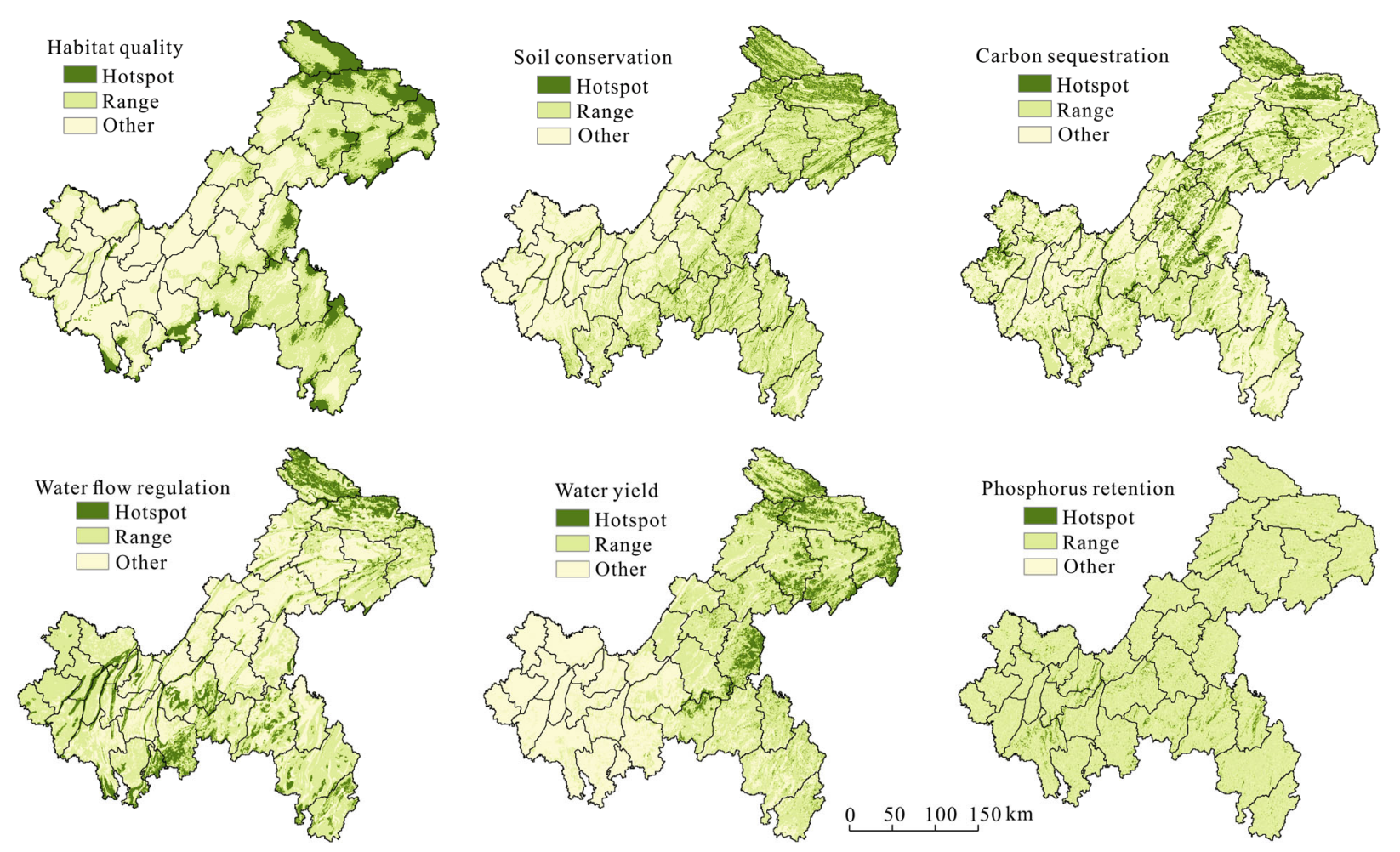

Fig. 5 Map of hotspots and ranges of habitat quality, soil conservation, carbon sequestration, water flow regulation, water yield and phosphorus retention
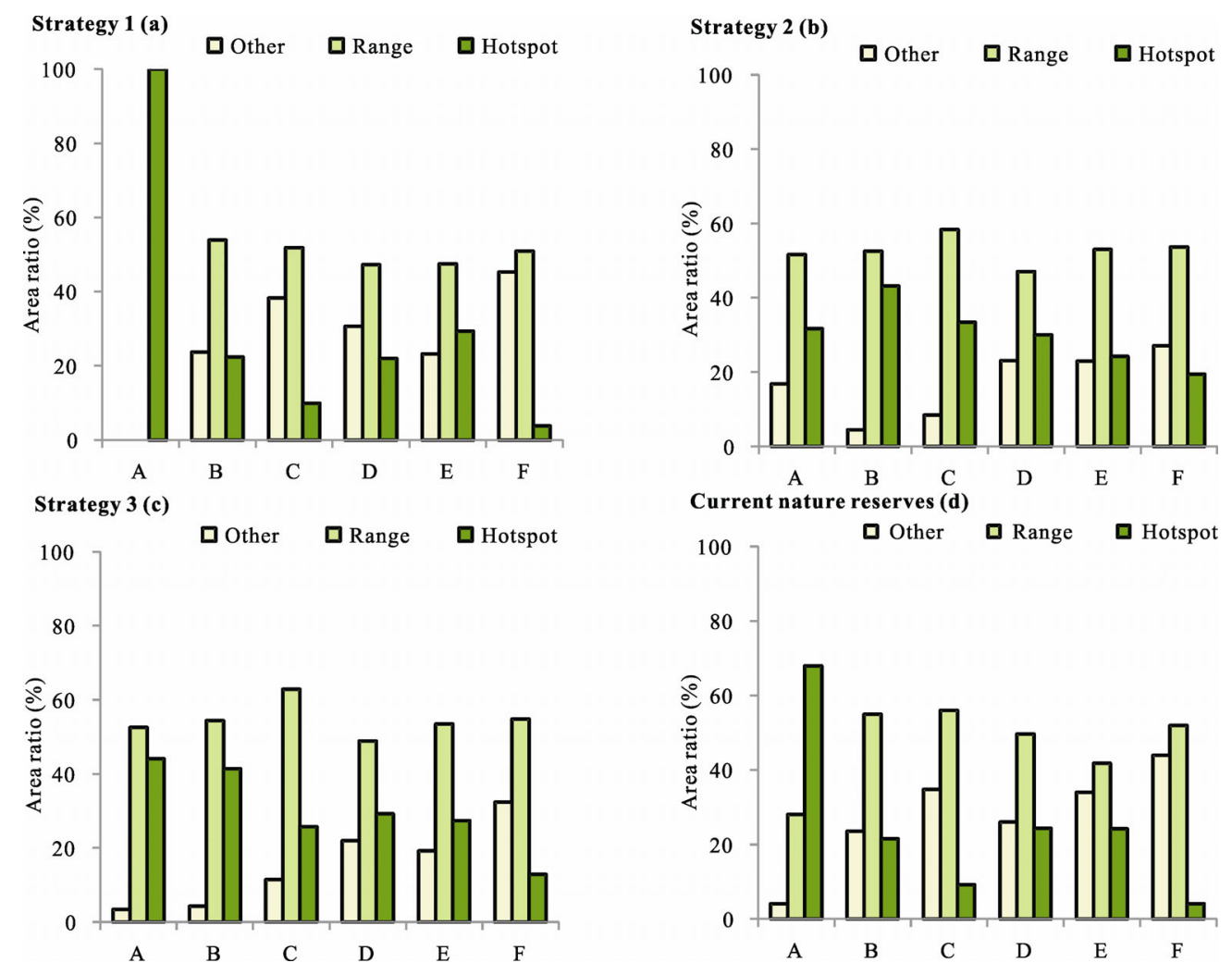

Fig. 6 Area percentages of hotspots and ranges of habitat quality, soil conservation, carbon sequestration, water flow regulation, water yield and phosphorus retention under different strategies. A, habitat quality; B, soil conservation; C, carbon sequestration; D, water flow regulation; E, water yield; F, phosphorus retention 


\section{Discussion}

This study explored the effectiveness of various strategies to optimize the planning and management of hotspot conservation. We found a higher degree of spatial overlap and congruence between the biodiversity hotspots and four ecosystem services hotspots including soil conservation, carbon sequestration, water flow regulation, and water yield (except phosphorus retention), which consisted with the findings of Turner et al. (2007). On the other hand, the unobvious spatial overlap and congruence between biodiversity and phosphorus retention, indicated that biodiversity do not correlated to the service of phosphorus retention. The areas with higher correlation between biodiversity and ecosystem services were found in the high altitude region filled with natural forested in the east mountain with less human disturbance (Liu et al., 2008; Liu et al., 2014). It is known that the carbon sequestration by the upper-elevation forests can mitigate to the global warming changes. Meanwhile, natural forests have positive impacts on the regulation of hydrologic dynamics through rainfall interception, contributing to maintaining slope stability during storms (Band et al., 2012). Thus, the conservation of biodiversity will guarantee the ecosystem services provision to a certain extent. Most of current conservation plans focused on the intrinsic value of biodiversity, and rarely considered the ecosystem services. In general, the conservation for ecosystem services can simultaneously contribute to biodiversity conservation, and vice versa. This can be supported by the similar outcomes from strategy 1 and 2, due to the biodiversity in maintaining the ecosystem function supports the supply of ecosystem services. Given the fact that biodiversity conservation related to habitat quality improvement, most conservation strategies were carried out in the northeastern and southeastern mountains aiming at restoring the high altitude natural vegetation. Few focused on the western parts of the study area where the local vegetation are superior in the supply of ecosystem services rather than natural habitat. Thus, it is extremely critical for maintaining protection of biodiversity and sustainable supply of ecosystem services by integrating biodiversity and ecosystem services into conservation strategies.

The three strategies and current nature reserves examined in this study represent four possible status for
Chongqing development. Among these strategies, strategy 1 presented a full-scale biodiversity conservation (100\% of habitat quality hotspots), comparing to the ecosystem services hotspots occupying $4 \%-29 \%$ of hotspot area. For ecosystem services conservation, however, strategy 2 would contribute to the conservation of $31 \%$ of the biodiversity hotspots, and $20 \%-43 \%$ of ecosystem services hotspots. Conservationists who are interested in either ecosystem services or biodiversity would prefer territorial expansion of the conservation areas as the prior objective. The proper objective for conservation, biodiversity conservation or ecosystem services improvement, affect the area chosen for priority conservation. By integrating biodiversity and ecosystem services into conservation strategies, strategy 3 would contribute to a conservation of $44 \%$ of the biodiversity hotspots, and $14 \%-42 \%$ of ecosystem services hotspots. Moreover, the current nature reserve did not improve ecosystem services at max potential by compared with strategy 3 . The results suggest that hotspot selection is importance in natural ecosystem management to optimize the conservation of biodiversity and ecosystem services.

\section{Conclusions}

Our study indicates that taking biodiversity and ecosystem services into account can optimise the conservation strategies for multiple ecosystem services and biodiversity conservation, and that biodiversity network would support a considerable supply of ecosystem services. The actual nature reserve under current conservation plans, focused on the intrinsic value of biodiversity, is the most important for biodiversity. However, it did not improve ecosystem services at max potential. The strategy 3 presents a much better and more environmentally sound future for Chongqing, based on these potential advantages over strategy 1 and 2 . Since it not only provide much biodiversity conservation, but also gain the enormous supply of ecosystem services in the long run. Thus, the adjustment of current conservation decisions was required by integrating biodiversity and ecosystem services into conservation strategies. Although this study have evaluated the biodiversity and ecosystem services based on USLE, CASA and InVEST model in view of spatial heterogeneity of climate, topography, vegetation, soil and land cover, it still has several limita- 
tions, which need to be exploring further. For example, the stand structure and growth of forest in regulating ecohydrological process and ecoatmospheric functions were also ignored, and some input parameters (e.g., the nutrient loading, evaporation coefficient and root depth) were defined based on the results of previous studies. Moreover, the calculated results of biodiversity and ecosystem services in this study were not the same as those in reality, but the potential maxima were based on the mathematical models. Nevertheless, this study provides an attempt to explore the biodiversity and ecosystem services with hotspots identification and optimization. In addition, our results could provide theoretical reference for examining the functions and efficiency of existing conservation strategies, which is vital for natural resources and ecosystem management.

\section{References}

Allen R G, Pereira L S, Raes D et al., 1998. Crop Evapotranspiration-Guidelines for Computing Crop Water RequirementsFAO Irrigation and Drainage Paper 56. Rome: FAO Press.

Bai Y, Zhuang C W, Ouyang Z et al., 2011. Spatial characteristics between biodiversity and ecosystem services in a humandominated watershed. Ecological Complexity, 8(2): 177-183. doi: 10.1016/j.ecocom.2011.01.007

Balvanera P, Daily G C, Ehrlich P R et al., 2001. Conserving biodiversity and ecosystem services. Science, 291(5511): 2047. doi: 10.1126/science.291.5511.2047

Band L E, Hwang T, Hales T C et al., 2012. Ecosystem processes at the watershed scale: mapping and modeling ecohydrological controls of landslides. Geomorphology, 137(1): 159-167. doi: 10.1016/j.geomorph.2011.06.025

Bookbinder M P, Dinerstein E, Rijal A et al., 1998. Ecotourism's support of biodiversity conservation. Conservation Biology, 12(6): 1399-1404.

Budyko M I, 1974. Climate and Life. San Diego, California: Academic Press.

Canadell J, Jackson R B, Ehleringer J B et al., 1996. Maximum rooting depth of vegetation types at the global scale. Oecologia, 108(4): 583-595. doi: 10.1007/BF00329030

Chan K M A, Shaw M R, Cameron D R et al., 2006. Conservation planning for ecosystem services. PLoS Biology, 4(11): 2138-2152. doi: 10.1371/journal.pbio.0040379

Chen L, Xie G D, Zhang C S et al., 2011. Modelling ecosystem water supply services across the Lancang River Basin. Journal of Resources and Ecology, 2(4): 322-327. doi: 10.3969/j.issn. 1674-764x.2011.04.005

Chen S T, Huang Y, Zou J W et al., 2012. Interannual variability in soil respiration from terrestrial ecosystems in China and its response to climate change. Science China Earth Sciences,
55(12): 2091-2098. doi: 10.1007/s11430-012-4464-6

Costanza R, d'Arge R, de Groot R et al., 1997. The value of the world's ecosystem services and natural capital. Nature, 387(6630): 253-260.

Crabtree R, Potter C, Mullen R et al., 2009. A modeling and spatio-temporal analysis framework for monitoring environmental change using NPP as an ecosystem indicator. Remote Sensing of Environment, 113(7): 1486-1496. doi: 10.1016/j.rse.2008. 12.014

Daily G C, Matson P A, 2008. Ecosystem services: from theory to implementation. Proceedings of the National Academy of Sciences of the United States of America, 105(28): 9455-9456. doi: 10.1073/pnas.0804960105

De Fries R S, Foley J A, Asner G P, 2004. Land-use choices: balancing human needs and ecosystem function. Frontiers in Ecology and the Environment, 2(5): 249-257. doi: 10.1890/ 1540-9295(2004)002

De Groot R S, Alkemade R, Braat L et al., 2010. Challenges in integrating the concept of ecosystem services and values in landscape planning, management and decision making. Ecological Complexity, 7(3): 260-272. doi: 10.1016/j.ecocom. 2009.10.006

Droogers P, Allen R G, 2002. Estimating reference evapotranspiration under inaccurate data conditions. Irrigation and Drainage Systems, 16(1): 33-45. doi: 10.1023/A:1015508322413

Egoh B, Rouget M, Reyers B et al., 2007. Integrating ecosystem services into conservation assessments: a review. Ecological Economics, 63(4): 714-721. doi: 10.1016/j.ecolecon.2007.04. 007

Egoh B, Reyers B, Rouget M et al., 2008. Mapping ecosystem services for planning and management. Agriculture, Ecosystems and Environment, 127(1-2): 135-140. doi: 10.1016/j.agee. 2008.03.013

Egoh B, Reyers B, Rouget M et al., 2009. Spatial congruence between biodiversity and ecosystem services in South Africa. Biological Conservation, 142(3): 553-562. doi: 10.1016/j. biocon.2008.11.009

Eigenbrod F, Anderson B J, Armsworth P R et al., 2009. Ecosystem service benefits of contrasting conservation strategies in a human-dominated region. Proceedings of the Royal Society B, 276(1699): 2903-2911. doi: 10.1098/rspb.2009.0528

Fu B J, Liu Y, Lu Y H et al., 2011. Assessing the soil erosion control service of ecosystems change in the Loess Plateau of China. Ecological Complexity, 8(4): 284-293. doi: 10.1016/j. ecocom.2011.07.003

Gao X, Huete A R, Ni W et al., 2000. Optical-biophysical relationships of vegetation spectra without background contamination. Remote Sensing of Environment, 74(3): 609-620. doi: 10.1016/S0034-4257(00)00150-4

Goldman R L, Tallis H, Kareiva P et al., 2008. Field evidence that ecosystem service projects support biodiversity and diversify options. Proceedings of the National Academy of Sciences of the United States of America, 105(27): 9445-9448. doi: 10. 1073/pnas.0800208105

Hargreaves G H, Samani Z A, 1985. Reference crop evapotran- 
spiration from temperature. Applied Engineering in Agriculture, 1(2): 96-99.

Hewlett J D, 1982. Principles of Forest Hydrology. University of Georgia Press, Athens, Georgia, USA.

Hickey R, 2000. Slope angle and slope length solutions for GIS. Cartography, 29(1): 1-8. doi: 10.1080/00690805.2000.9714334

Hunter L M, Manuel D J, Gonzalez G et al., 2003. Population and land use change in the California Mojave: natural habitat implications of alternative futures. Population Research and Policy Review, 22(4): 373-397. doi: 10.1023/A:1027311225410

Janzen D H, 1998. Gardenification of wildland nature and the human footprint. Science, 279(5355): 1312-1313. doi: 10.1126/ science.279.5355.1312

Jin Z, Qi Y C, Dong Y S, 2007. Storage of biomass and net primary productivity in desert shrubland of Artemisia ordosica on Ordos Plateau of Inner Mongolia, China. Journal of Forestry Research, 18(4): 298-300. doi: 10.1007/s11676-007-0059-z

Jonsson P, Eklundh L, 2002. Seasonality extraction by function fitting to time-series of satellite sensor data. IEEE Transactions on Geoscience and Remote Sensing, 40(8): 1824-1932. doi: 10.1109/TGRS.2002.802519

Jonsson P, Eklundh L, 2004. TIMESAT-A Program for analyzing time-series of satellite sensor data. Computers \& Geosciences, 30(8): 833-845. doi: 10.1016/j.cageo.2004.05.006

Konarska K M, Sutton P C, Castellon M, 2002. Evaluating scale dependence of ecosystem service valuation: a comparison of NOAA-AVHRR and Landsat TM datasets. Ecological Economics, 41(3): 491-507. doi: 10.1016/S0921-8009(02)00096-4

Li T H, Li W K, Qian Z H, 2010. Variations in ecosystem service value in response to land use changes in Shenzhen. Ecological Economics, 69(7): 1427-1435. doi: 10.1016/j.ecolecon.2008. 05.018

Li X S, Wu B F, Wang H et al., 2011. Regional soil erosion risk assessment in Hai Basin. Journal of Remote Sensing, 15(2): 372-387. doi: 1007-4619 (2011) 02-372-16

Liu S L, Cui S L, Dong S K et al., 2008. Evaluating the influence of road networks on landscape and regional ecological risk: a case study in Lancang River Valley of Southwest China. Ecological Engineering, 34: 91-99. doi: 10.1016/j.ecoleng.2008. 07.006

Liu S L, Dong Y H, Deng L et al., 2014. Forest fragmentation and landscape connectivity change associated with road network extension and city expansion: a case study in the Lancang River Valley. Ecological Indicators, 36: 160-168. doi: 10. 1016/j.ecolind.2013.07.018

Lufafa A, Tenywa M M, Isabirye M et al., 2003. Prediction of soil erosion in a Lake Victoria basin catchment using a GIS-based Universal Soil Loss model. Agricultural Systems, 76(3): 883-894. doi: 10.1016/S0308-521X(02)00012-4

Luo T X, 1996. Patterns of Net Primary Productivity for Chinese Major Forest Types and Its Mathematical Models. Chinese Academy of Sciences.

Miao C Y, Duan Q Y, Sun Q H et al., 2014. Assessment of CMIP5 climate models and projected temperature changes over Northern Eurasia. Environmental Research Letters, 9(5): 055007. doi: 10.1088/1748-9326/9/5/055007

Millennium Ecosystem Assessment, 2005. Millennium Ecosystem Assessment Synthesis Report. Washington D C, Island Press. http://www.millenniumassessment. org/en/Synthesis.aspx.

McCann K S, 2000. The diversity-stability debate. Nature, 405(6783): 228-233. doi: 10.1038/35012234

Monteith J L, 1972. Solar radiation and productivity in tropical ecosystems. Journal of Applied Ecology, 9(3): 747-766. doi: $10.2307 / 2401901$

Myneni R B, Maggion S, Iaquinta J et al., 1995. Optical remote sensing of vegetation: modeling, caveats, and algorithms. Remote Sensing of Environment, 51(1): 169-188. doi: 10.1016/ 0034-4257(94)00073-V

Nelson E, Mendoza G, Regetz J et al., 2009. Modeling multiple ecosystem services, biodiversity conservation, commodity production, and tradeoffs at landscape scales. Frontiers in Ecology and the Environment, 7(1): 4-11. doi: 10.1890/080023

$\mathrm{Ni}$ J, 2004. Estimating net primary productivity of grasslands from field biomass measurements in temperate northern China. Plant Ecology, 174(2): 217-234. doi: 10.1023/B:VEGE.00000 49097.85960.10

Onaindia M, de Manuel B F, Madariaga I et al., 2013. Co-benefits and trade-offs between biodiversity, carbon storage and water flow regulation. Forest Ecology and Management, 289(1): 1-9. doi: 10.1016/j.foreco.2012.10.010

Orme C D L, Davies R G, Burgess M et al., 2005. Global hotspot of species richness are not congruent with endemism or threat. Nature, 436(7053): 1016-1019. doi: 10.1038/nature03850

Potter C S, Randerson J T, Field C B et al., 1993. Terrestrial ecosystem production: a process model based on global satellite and surface data. Global Biogeochemical Cycles, 7(4): 811841. doi: 10.1029/93GB02725

Potter C S, Klooster S A, Brooks V, 1999. Interannual variability in terrestrial net primary production: exploration of trends and controls on regional to global scales. Ecosystems, 2(1): 36-48. doi: 10.1007/s100219900056

Potter C S, Klooster S, Myneni R et al., 2003. Continental scale comparisons of terrestrial carbon sinks estimated from satellite data and ecosystem modeling 1982-1998. Global and Planetary Change, 39(3-4): 201-213. doi: 10.1016/j.gloplacha.2003. 07.001

Prendergast J R, Quinn R M, Lawton J H et al., 1993. Rare species, the coincidence of diversity hotspot and conservation strategies. Nature, 365: 335-337. doi: 10.1038/365335a0

Reyers B, Polasky S, Heather T et al., 2012. Finding common ground for biodiversity and ecosystem services. Bioscience, 62(5): 503-507. doi: 10.1525/bio.2012.62.5.12

Sedjo R, Sohngen B, 2012. Carbon sequestration in forests and soils. Annual Review of Resource Economics (Annual Reviews), 4: 127-144. doi: 10.1146/annurev-resource-083110115941

Tallis H T, Ricketts T, Nelson E et al., 2010. InVEST 1.005 Beta User's Guide. The Natural Capital Project. Stanford. United States Department of Agriculture, 1990. EPIC-Erosion/productivity Impact Calculator 1. Model Documentation. Techni- 
cal Bulletin Number 1768. Washington DC.

Turner W R, Brandon K, Brooks T M et al., 2007. Global conservation of biodiversity and ecosystem services. Bioscience, 57(10): 868-873. doi: 10.1641/B571009

Van JaarsveldA S, Freitag S, Chown S L et al., 1998. Biodiversity assessment and conservation strategies. Science, 279(5359): 2106-2108. doi: 10.1126/science.279.5359.2106

Van Remortel R D, Hamilton M E, Hickey R J, 2001. Estimating the LS-factor for RUSLE through iterative slope length processing of digital elevation data within ArcInfo grid. Cartography, 30(1): 27-35. doi: 10.1080/00690805.2001.9714133

Vitousek P M, Mooney H A, Lubchenco J et al., 1997. Human Domination of Earth's Ecosystems. Science, 277(5325): 494-499. doi: 10.1126/science.277.5325.494

Wischmeier W H, Smith D D, 1978. Predicting Rainfall Erosion Losses-A Guide to Conservation Planning. Agriculture Handbooks (USA), No. 537, Washington D C.

Zhang C Q, Li W H, Zhang B et al., 2012. Water yield of Xitiaoxi River Basin based on InVEST Modeling. Journal of Resources and Ecology, 3(1): 50-54. doi: 10.5814/j.issn.1674-764x.2012.
01.008

Zhang K L, Shu A P, Xu X L et al., 2008. Soil erodibility and its estimation for agricultural soils in China. Journal of Arid Environments, 72(6): 1002-1011. doi: 10.1016/j.jaridenv.2007. 11.018

Zhang L, Dawes W R, Walker G R, 2001. Response of mean annual evapotranspiration to vegetation changes at catchment scale. Water Resources Research, 37(3): 701-708. doi: 10. 1029/2000WR900325

Zhao B, Kreuter U, Li B et al., 2004. An ecosystem service value assessment of land-use change on Chongming Island, China. Land Use Policy, 21(2): 139-148. doi: 10.1016/j.landusepol. 2003.10.003

Zhou W Z, Liu G H, Pan J J et al., 2005. Distribution of available soil water capacity in China. Journal of Geographical Sciences, 15(1): 3-12. doi: 10.1007/BF02873101

Zhu W, Pan Y, He H et al., 2006. Simulation of maximum light use efficiency for some typical vegetation types in China. Chinese Science Bulletin, 51(4): 457-463. doi: 10.1007/s11434006-0457-1 